\title{
TRIBUTE TO SIR LUDWIG GUTTMANN
}

\section{(3 July I899 to I8 March I980)}

To record the death of Paraplegia's founding editor is a sad and daunting task, especially as it is less than a year after our Journal produced Ludwig's 8oth birthday number to celebrate his splendid service to humanity.

We shall do what we can and it seems best to begin with a simple account of his life and the stages of his work. Ludwig Guttmann was born in I899 in Tost in Upper Silesia, where his father was the innkeeper and distiller of the Hotel zur Post. In 1902 the family moved to Koenigshütte, also in Upper Silesia, a

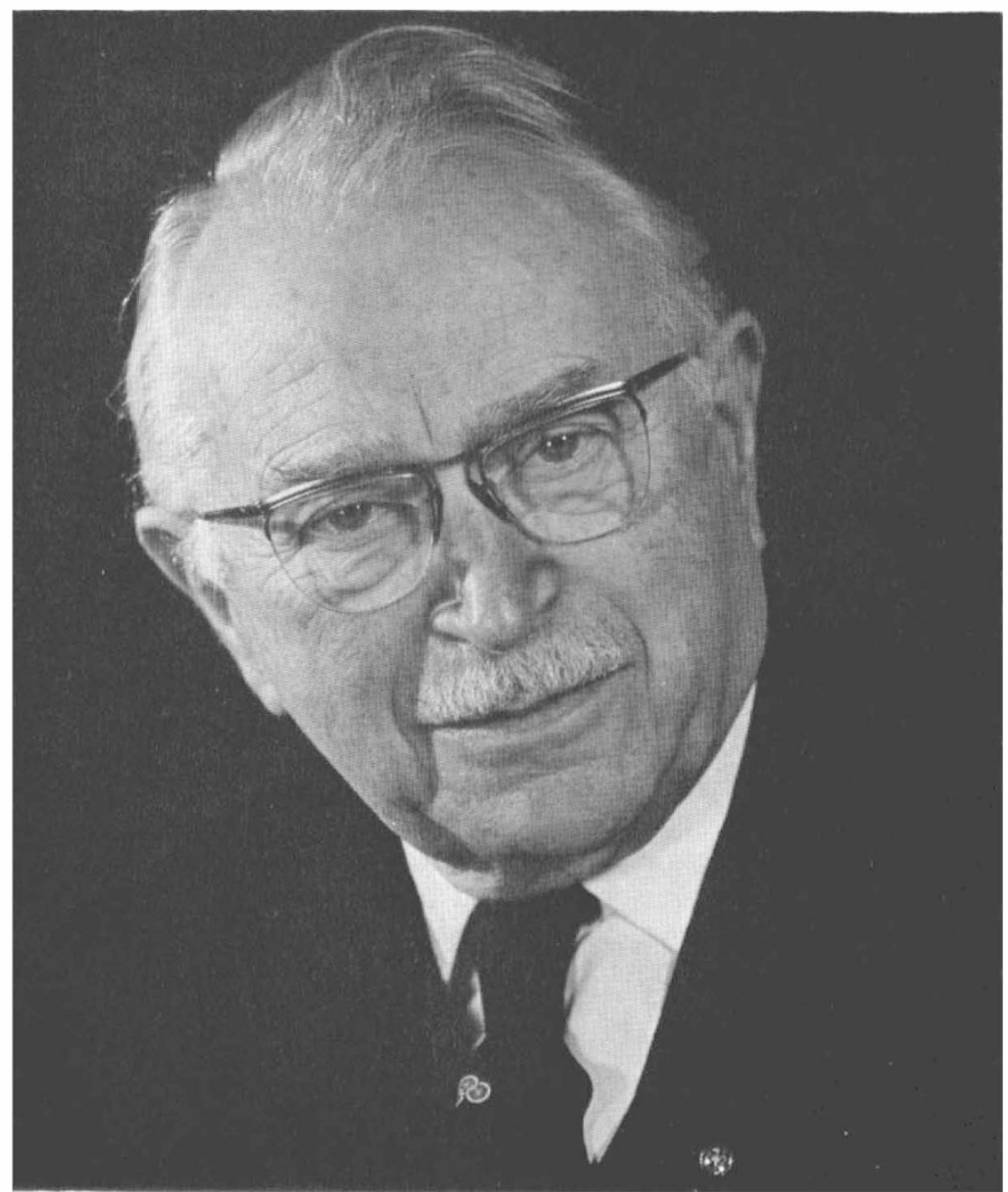

town of 70,000 inhabitants with a large iron foundry in a coal mining districtin fact an area similar in many ways to Newcastle. His father continued his occupation of innkeeper and distiller in their new home.

Ludwig began his medical studies in Breslau in I9I 8 but a year later continued his course in Freiburg. During these early years he founded a 'Wanderbund'-a

I $8 / 3-\mathrm{A}$ 
rambling club-for young Jewish people, with whom he spent many happy times, walking in the Black Forest.

It was in this group that he met Else Samuel, his future wife, herself a considerable personality and a humanitarian, and who was to give him such unstinted support during his long career. He passed his final examination in Freiburg in I923 achieving excellent marks in all subjects except surprisingly in neurology and psychiatry. Incidentally, one of his examiners was Ashoff. There is one particular incident which was probably of great significance. After finishing school in 1917, Ludwig spent the last year of the First World War as a volunteer in an accident hospital, where he first came into contact with paraplegia, in the person of a strapping young coal miner with a fracture of the spine. When Ludwig began to write up his notes he was told, 'Don't bother, he'll be dead in a few weeks'. And so he was, after developing massive bed sores and gross urinary infection. The memory of this tragedy haunted Ludwig for many years.

His father had moved to Breslau in I92 I because of religious persecution by the Poles after the end of the First World War and Ludwig also returned to Breslau after qualification as his father could not continue to support him in Freiburg. In those days junior doctors received no salary and even had to pay for their meals and lodgings. One story which he used to tell about his early career was that, after qualification, he wished to be a paediatrician and one day was actually on his way to an interview with the Professor of Paediatrics in the hope of obtaining a junior post. In the hospital he met a friend who told him that it was no use applying for a post in paediatrics as there was already a large crowd waiting for one solitary job. Fortunately for us, and for posterity, Ludwig made a lightning decision and walked downstairs to apply for and to obtain a junior post in the Department of Neurology, where he worked for the famous Professor Foerster, first as house surgeon and later on as registrar. He always regarded this period with Foerster (which lasted until I928), as a vital preparation for his subsequent career. Foerster was a hard and exacting taskmaster, for whom only the best was possible. During this time Ludwig impressed his chief by using his new methods to obtain healing in a paraplegic patient with extensive pressure sores. Already by 1927 there were rumblings of anti-semitism when a Nazi councillor in Breslau asked, 'Why does Foerster have only Jewish assistants?' but Foerster replied that he put knowledge before religion. While working with Foerster Ludwig commenced his studies on the neuro-regulation of sweating and invented the quinizarine sweat test, this being the subject of his thesis for the Docentur. Ludwig next spent a year as neurosurgeon to a large hospital in Hamburg, working with Professor Weigand but in 1929 he accepted the post of first assistant to Foerster, a post he held until 1933 when all Jewish doctors were dismissed. He maintained contact with Foerster until 1937 and presented his old chief with a 6oth birthday 'Festschrift' but was not allowed to attend the official celebrations. At this difficult juncture Ludwig joined the Jewish Hospital in Breslau as Director of Neurology and Neurosurgery and continued to be nationally in great demand for his expertise and clinical judgement.

For some time Ludwig continued to hope that Nazism would not last and refused invitations to emigrate to Russia, America and Portugal. However, in September 1938 he was ordered to discharge all non-Jewish patients from the Jewish Hospital. Later that year, when thousands of Jews were taken to concentration camps, Ludwig was summoned by the local Gestapo Commissar to explain why there had been 63 male admissions to his hospital. He had to present every case to the Nazis and explain the nature of the illness, so justifying the hospital 
admission. He managed to save all but three of these from being sent to the concentration camp. Ludwig realised then that he would have to leave Germany and, with a wife, two children and no money, he arrived in Britain on I4 March 1939 as a refugee sponsored by Hugh Cairns. Under the auspices of the Society for the Protection of Science and Learning he commenced research work in Oxford at Balliol College on nerve injuries and later collaborated with Trueta and Whitteridge; with the latter he published an original paper on the pronounced cardiovascular changes in patients with lesions at or above the level of $\mathrm{T}_{5}$ during distension of the urinary bladder.

Ludwig was a meticulous research worker and was brought up to believe that pathophysiology, the study of disturbances of function in disease was of fundamental importance. All this was to prove the prelude to his life's work and which virtually began in 1944 when the Government, at the instigation of George Riddoch, asked him to start the first special centre for spinal injuries at Stoke Mandeville Hospital.

Shortly afterwards paraplegic patients from the D-day landings were admitted and the National Spinal Injuries Centre was launched. Ludwig had to be in the wards all day and indeed part of the night as he had little assistance at that time and it was necessary to train the ward orderlies in the two-hourly routine turning, quite apart from the meticulous care needed in catheterisation. One of his earliest patients, now a retired clergyman, said that when he arrived in Ward 2X at Stoke Mandeville he met for the first time the man who was to bring back the word hope into his miserable life. Appropriately, in 1945, Ludwig Guttmann published a detailed paper entitled 'New Hope for Spinal Cord Sufferers' in the Medical Times. Within Io years of the opening of the Stoke Mandeville Spinal Centre, he was able to publish a review of the first 1000 patients.

Those who have started working in paraplegia during the last 15 or 20 years have entered a field of promise. But it is important to appreciate that all this has been achieved since the Second World War before which an injury to the spinal cord was virtually a death sentence. Ludwig tackled this unpromising field and, at first by himself and later with a small but increasing group of colleagues, effected a complete transformation of the dismal scene. Among the sagas of the sulphonamides, the antibiotics, the advances in genetics, immunology and surgery, his work in paraplegia takes its rightful place. The centre at Stoke became the Mecca for all those interested and in 1948 he founded the Annual Stoke Mandeville Games and which, in 1952, became the first international sports for the paralysed. Coincident with the Annual Games a scientific meeting was inaugurated and from this, in turn, developed the International Medical Society of Paraplegia, of which Ludwig was the first president and the first recipient of the annual medal. Always carried forward by his enthusiasm and dedication the next logical step was the journal Paraplegia, of which he was the editor till his death.

After his retirement from the National Health Service in 1967 his many activities remained unabated especially his visits abroad. He also raised large sums of money for the huge modern sports stadium for the disabled (the first of its kind in the world), and which he continued to run up to the time of his death.

Last year the May edition of Paraplegia was entirely devoted to special papers and appreciations from present and previous colleagues to commemorate his 8oth birthday. In that issue there were numerous stories of his many kindnesses and Maury commented that in France he was frequently referred to as 'papa' though he did not know whether this meant 'father' or 'pope', probably a little of both. 
Many honours, distinctions and awards, including a number of honorary degrees were showered upon him and in 1966 Ludwig Guttmann was knighted by Her Majesty. He was also elected a Fellow of the Royal Society.

Space does not permit full lists of these numerous tributes-tributes from the USA, France, Germany, Spain, South Africa, South America, Japan, Scandinavia, Israel, Italy, India, Pakistan and other parts of the world.

Ludwig Guttmann was a man of dedication, of purpose, a tireless searcher after truth and intolerant of carelessness, inefficiency or low standards of treatment. But at the same time he had a kind and genial personality with a great gift of friendship. He was always genuinely pleased to meet his colleagues and had hundreds of friends around the world. Many great men are remote and tend to dissociate themselves from the daily scene but Ludwig not only remembered his friends but remembered all about them, their families and their work.

Always a brilliant neurologist his research interests (starting in his early days), continued to the last, his contributions to medical literature reaching the figure of I50. It is significant that one of his last papers was entitled 'Past, present and future of the specialised service for spinal cord sufferers' in which he emphasised the importance of forward planning of new spinal centres.

No great man lives in vain. The history of the world, as Carlyle said, is the biography of great men and Ludwig Guttmann has made no mean contribution to it. It is difficult to imagine the discipline of paraplegia without him, without his galvanism and his infectious enthusiasm.

We shall sorely miss him.

J. Cosbie Ross

PHILliP HARRIS

\section{Questionnaire on Spinal Injury Centres}

A large number of Questionnaires have been completed, and returned to $\mathrm{Dr}$ Hans Frankel, Hon. Secretary, I.M.S.P., National Spinal Injuries Centre, Stoke Mandeville Hospital, Aylesbury, Bucks, England, and these are being analysed (all information is being kept confidential).

However, there are still many completed Questionnaire Forms to be returned, and we would be grateful if this could be done as quickly as possible. If anyone wishes further Forms, please write forthwith to Dr Frankel.

Phillip HARRIS 